\title{
Estudio de la curvatura de piezas crudas en pavimentos cerámicos de gres
}

\author{
A. DE PABLOS, P. MIRANZO, M. I. OSENDI, J.C. ROMERO' ${ }^{1}$, P. CRESPO ${ }^{1}$, L. GARGALLO ${ }^{1}$, M.A. BENGOECHEA ${ }^{1}$ \\ Instituto de Cerámica y Vidrio. CSIC. 28500 Arganda del Rey. Madrid \\ ${ }^{1}$ Gres de Nules-Keraben. 12520 Nules. Castellón
}

\begin{abstract}
Las baldosas cerámicas sufren deformaciones durante su proceso en línea de producción. Cuando las baldosas salen de la prensa presentan una superficie plana, pero en las siguientes etapas de la línea de producción la superficie de las muestras se humedece, produciendose gradientes de temperatura y humedad que dan lugar a una deformación por curvatura de la pieza. El objetivo de este trabajo es estudiar dicha curvatura y las propiedades mecánicas de las baldosas en función de la humedad absorbida en dos tipos de pastas cerámicas.
\end{abstract}

Palabras Clave: gres, curvatura, humedad, modulo de elasticidad, resistencia mecánica.

\section{Study of the curvature of green pieces in stoneware ceramic tiles}

Ceramic tiles undergo some deformations on the production line. After pressing, tiles are flat but, in subsequent stages of the production line, surfaces are wetted producing temperature and water gradients across their thickness. These gradients generate curvature in the tiles and therefore deformations in the pieces. The aim of the present work has been to measure the curvature and the mechanical properties of the tiles as a function of the water absorption for two types of ceramic pastes.

Key words: stoneware tiles, curvature, water absorption, elastic modulus, strength

\section{INTRODUCCIÓN}

Durante el proceso en línea de producción se observa que las baldosas cerámicas, especialmente los formatos grandes, experimentan una ligera curvatura que varía durante las diversas etapas, como son el secado, la aplicación de agua, el paso por campanas y el serigrafíado. Dicha curvatura da lugar a una deformación de la pieza (1), que durante el proceso de serigrafiado puede introducir tensiones en la baldosa y, por ello, ser responsable de parte de las roturas que se producen en la línea pues, en algún caso, podría alcanzarse la tensión de rotura de la pieza (2). Resulta interesante, por tanto, determinar el nivel de curvatura de las baldosas cerámicas, analizando los parámetros que pueden influir en ella y su efecto en las roturas.

En el presente trabajo se ha cuantificado el grado de curvatura en función de la humedad absorbida por baldosas crudas de dos tipos de gres: pasta roja y pasta blanca. Para este estudio se ha tenido en cuenta la influencia de la temperatura y de la porosidad de las baldosas.

Con objeto de evaluar la influencia del tamaño de poro de las muestras sobre la curvatura se han realizado ensayos sobre muestras preparadas en el laboratorio, con diferentes distribuciones de poros.

Por otra parte, el grado de humedad puede influir en el comportamiento mecánico-elástico de las piezas crudas. Para evaluarlo, se midieron tanto la resistencia mecánica como el módulo de elasticidad de placas preparadas a partir de baldosas crudas para varios niveles de humedad.

\section{INTRODUCTION}

In the production line, ceramic tiles, particularly the larger sizes, experience some slight curvature which varies during the different stages of the glazing process. This curvature produces a deformation of the piece (1), which may introduce stresses in the tile during the silk-screen printing process and consequently be responsible for fractures occurring on the line, since the fracture strength of the piece may be reached (2). Hence, it is interesting to determine the level of curvature of ceramic tiles by analyzing the parameters which may influence it and its effect on tile fracture.

In this work, the degree of curvature was quantified as a function of the absorbed water by green tiles of two types of stoneware: red paste and white paste. For this study, the influence of temperature and porosity of the tiles were taken into account. To evaluate the influence of the pore size on the curvature, samples with different pore size distributions were purposely prepared in the laboratory,.

Moreover, the degree of water absorption can affect the mechanical-elastic behavior of the green tiles. To evaluate this effect both the strength and the elastic modulus of pieces machined from green tiles were measured at several levels of water absorption.

Finally, the results of curvature, strength and modulus of elasticity as a function of the absorbed water were compared with the response of both stonewares on the production line, considering the water absorption levels occurring on line. 
Finalmente, los resultados de curvatura, resistencia y elasticidad en función de la humedad se contrastaron con la respuesta en línea de las ambas pastas, considerando los niveles de humedad durante el proceso en linea.

\section{PROCEDIMIENTO EXPERIMENTAL}

Con el fin de humectar las piezas de forma controlada se diseño un sencillo dispositivo, que se muestra esquemáticamente en la Figura 1. Se utilizaron placas de $\mathrm{Lx} 10 \mathrm{~cm} \times 0.8 \mathrm{~cm}(\mathrm{~L}=$ longitud de la baldosa, $33 \mathrm{~cm}$ para la pasta roja y $34.5 \mathrm{~cm}$ para la pasta blanca) cortadas de baldosas crudas. Las piezas se secaron en una estufa a $110{ }^{\circ} \mathrm{C}$ durante $20 \mathrm{~h}$ y a continuación se enfriaron en un desecador para evitar la absorción de agua; posteriormente, se impregnaron con agua mediante el paso por un rodillo, tal como se muestra en la Figura 1. Después de humedecer la superficie, la baldosa se pesaba para conocer la cantidad de agua absorbida y se colocaba debajo de dos sensores de desplazamiento vertical, previamente tarados con la baldosa seca (ver Figura 2). Se anotaba el desplazamiento después de mantener la pieza durante un minuto en esta posición. Los resultados obtenidos por este procedimiento se representaron gráficamente como desplazamiento del punto medio de la placa en función de la humedad, donde cada punto correspondía a la media de tres medidas.

Para los ensayos realizados sobre muestras recién sacadas de la estufa, se siguió el mismo procedimiento, controlando la pérdida de humedad antes y después de realizar la medida de la curvatura.

El efecto del tamaño de poro sobre el grado de curvatura se analizó en placas de pasta roja de $8 \mathrm{~cm} \times 3 \mathrm{~cm} \times 0.5 \mathrm{~cm}$. Estas placas se obtuvieron a partir de lotes con distinto nivel de rechazo por un tamiz de $63 \mu \mathrm{m}$ (Tabla1), obtenidos usando diferentes tiempos de molienda en un molino de $200 \mathrm{Kg}$. Estas piezas se conformaron a distintas presiones, 22.5 y $25.0 \mathrm{MPa}$.

Las distribuciones de tamaño de poro de las muestras se determinaron mediante la técnica de porosimetría de mercurio (Mod. Micomeritics Autopore II 9215) y el tamaño medio de partícula de los polvos a distintos rechazos se realizó mediante un analizador láser de partículas (Mastersizer S Ver. 2.18).

El módulo de rotura se medió mediante flexión en tres puntos con una distancia entre apoyos de $10 \mathrm{~cm}$, utilizando una máquina universal de ensayos (Instron mod. 114) y probetas de $16 \mathrm{~cm} \times 10$ $\mathrm{cm} \times 0.8 \mathrm{~cm}$, mecanizadas a partir de baldosas crudas. El módulo de rotura se determinó en una serie de 10 probetas secadas en la estufa a $110^{\circ} \mathrm{C}$ durante $20 \mathrm{~h}$ y en otra serie de 10 probetas con un porcentaje de humedad absorbida del $1 \%$. Estos ensayos se realizaron para cada tipo de pasta.

El módulo de elasticidad dinámico (E) se obtuvo a partir de la frecuencia propia de vibración en flexión de placas rectangulares de $10 \mathrm{~cm} \times 5 \mathrm{~cm} \times 0.8 \mathrm{~cm}$, mecanizadas a partir de las baldosas crudas de ambas pastas, utilizando un equipo Grindosonic mod.

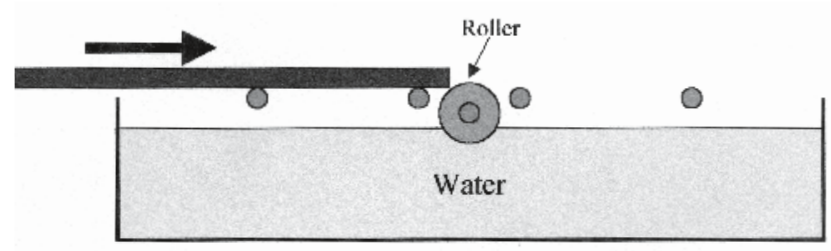

Figura 1.-Dispositivo para humedecer la superficie de las baldosas.

Figure 1. Laboratory device used to wet the tiles.

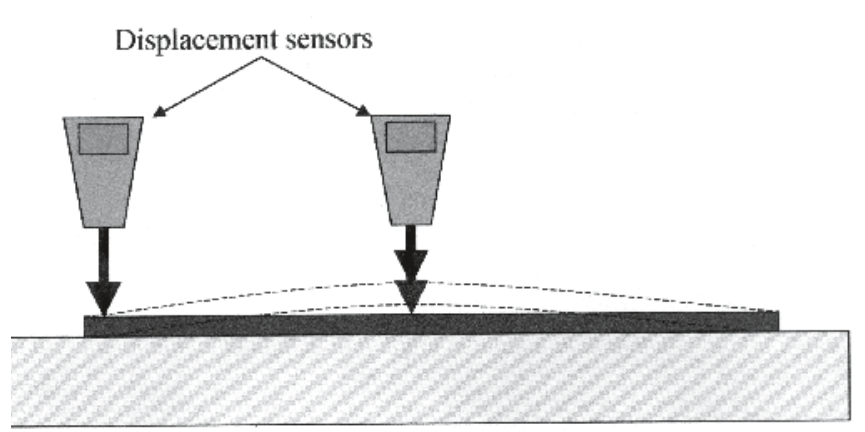

Figura 2.-Dispositivo para medir el desplazamiento en el punto medio de la superficie de la baldosa.

Figure 2. Scheme employed to measure the relative vertical displacement of the middle point of the tiles.

TABLA 1. REFERENCIA DADA A LAS PLACAS Y CORRESPONDIENTE NIVEL DE RECHAZO POR UN TAMIZ DE $63 \square$ M DEL POLVO UTILIZADO PARA PREPARARLAS.

TABLE 1. REFERENCE NUMBER AND REJECTION PERCENTAGE FOR POWDERS OF RED STONEWARE MILLED AT DIFFERENT TIMES.

\begin{tabular}{|c|c|}
\hline REFERENCE & $\begin{array}{c}\text { REJECTION PERCENTAGE } \\
\text { ( } 63 \text { um screen })\end{array}$ \\
\hline $8 \%$ & $7.8 \%$ \\
$5 \%$ & $5.3 \%$ \\
$2 \%$ & $2.4 \%$ \\
\hline
\end{tabular}

\section{EXPERIMENTAL PROCEDURE}

A simple device was designed to wet the pieces in a controlled way, as shown in Figure 1. Pieces of Lx10 $\mathrm{cm} \times 0.8 \mathrm{~cm}(\mathrm{~L}=$ length of the tile, $33 \mathrm{~cm}$ for the red paste and $34.5 \mathrm{~cm}$ for the white paste) cut from green tiles were used. The pieces were dried in an oven at $110^{\circ} \mathrm{C}$ for $20 \mathrm{~h}$ and then cooled in a desiccator to prevent water absorption; subsequently, they were wetted by using a water bath provided with a roller, as is shown in Figure 1. Afterwards, the tile was weighed to measure the amount of absorbed water and placed beneath two vertical displacement sensors, previously tared using the dry tile (see Figure 2). After one minute, the corresponding displacement was measured. Results were plotted as the displacement of the middle point of the piece versus the water absorption. Each point was the average of three measurements.

The same procedure was used on hot samples directly taken from the oven measuring the absorbed water before and after the test.

The effect of pore size on the degree of curvature was analyzed only for the red paste in pieces of $8 \mathrm{~cm} \times 3 \mathrm{~cm} \times 0.5 \mathrm{~cm}$ in size. These samples were machined from batches with increasing rejection levels through a $63 \mu \mathrm{m}$ sieve (Table1). These batches were prepared by using different milling times in a $200 \mathrm{Kg}$ capacity mill. The pieces were compacted at two pressures, 22.5 and $25.0 \mathrm{MPa}$.

The pore size distributions were determined by means of mercury porosimmetry (Micomeritics Autopore II 9215 Mod.). The average particle size of the powders with different rejection levels was measured by using a laser particle analyzer (Mastersizer S Ver. 2.18).

The strength was measured by three point bending texts using a span of $10 \mathrm{~cm}$, in an universal testing machine (Instron 


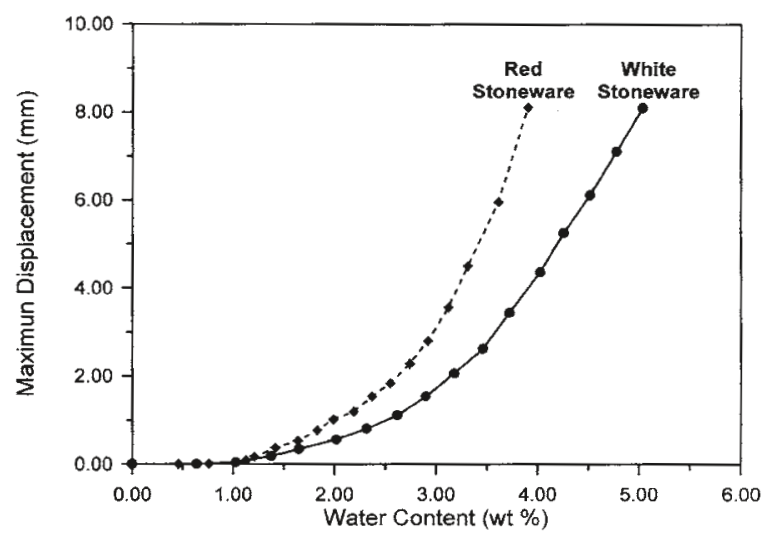

Figura 3.- Desplazamiento del punto medio de la placa en función de la humedad absorbida a temperatura ambiente.

Figure 3. Displacement of the plate vs amount of absorbed water for the white and red stoneware tiles at room temperature.

MK5. La validez de la técnica de ultrasonidos para la medida de E en probetas crudas ha sido probada (2) anteriormente en piezas crudas de gres porcelánico. El módulo de elasticidad se midió en muestras recién sacadas de una estufa a $110^{\circ} \mathrm{C}$, y después de $1 \mathrm{~h}$, $3 \mathrm{~h}, \mathrm{y} 24 \mathrm{~h}$, para variar el contenido de humedad en las mismas.

El contenido de humedad de las baldosas durante las distintas etapas de la línea de producción se determinó por procedimientos de pesada.

\section{RESULTADOS}

En la Figura 3 se muestran las gráficas del desplazamiento del punto medio de las muestra en función de la humedad absorbida, observandose que las piezas de gres rojo se curvan más que las de gres blanco para la misma cantidad de agua absorbida, especialmente para humedades superiores a $1.2 \%$ en peso.

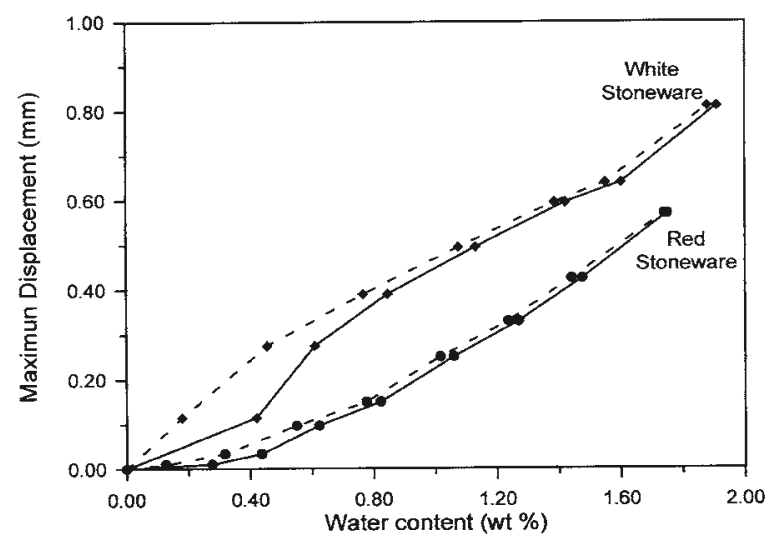

Figura 5.- Desplazamiento del punto medio de la placa, recién sacada de la estufa, en función del agua absorbida. Las líneas continúas indican el agua absorbida después de impregnar la muestra. La línea de puntos indica el agua en la muestra después de medir el desplazamiento.

Figure 5. Displacement of the plate vs amount of absorbed water for the red and white hot stonewares. Continuous lines gives the water absorbed initially by the samples and dashed lines is the amount of water that remains after the displacement measurement.

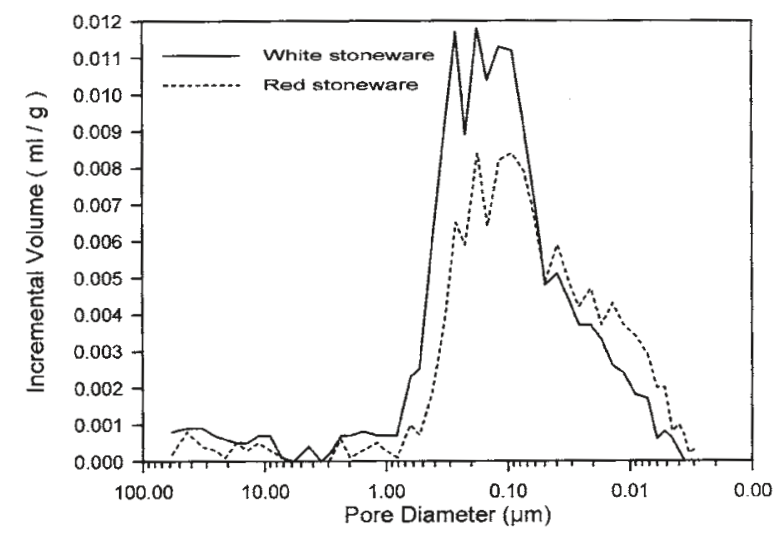

Figura 4.- Volumen de poros en función del diámetro medio del poro para ambas pastas.

Figure 4. Graphs of pore volume as a function of pore diameter for both stonewares.

mod. 114). Test specimens were bars of $16 \mathrm{~cm} \times 10 \mathrm{~cm} \times 0.8 \mathrm{~cm}$, machined from green tiles. The strength was determined in a set of 10 specimens dried at $110^{\circ} \mathrm{C}$ for $20 \mathrm{~h}$ and in another set of 10 specimens with $1 \mathrm{wt} \%$ of absorbed water. These experiments were carried out for both pastes.

The dynamic elastic modulus (E) of both pastes was calculated from the bending resonance frequency of rectangular plates of dimensions $10 \mathrm{~cm} \times 5 \mathrm{~cm} \times 0.8 \mathrm{~cm}$, machined from green tiles, using a Grindosonic mod. MK5 equipment. The validity of the ultrasonic technique for measuring $\mathrm{E}$ in green specimens has been previously proved (2) in green pieces of porcelain stoneware. The elastic modulus was measured in samples directly removed from the oven at $110^{\circ} \mathrm{C}$ and also after $1 \mathrm{~h}, 3 \mathrm{~h}$ and $24 \mathrm{~h}$ at room temperature, to vary the water content of the samples.

Weighing procedures were used to determine the water content of the tiles at the different stages of the production line.

\section{RESULTS}

Figure 3 represents the displacement of the middle point of the samples as a function of the absorbed water, showing that the pieces of red stoneware curve more than the white stoneware pieces for the same level of absorbed water, especially in the case of water absorption higher than $1.2 \mathrm{wt} . \%$.

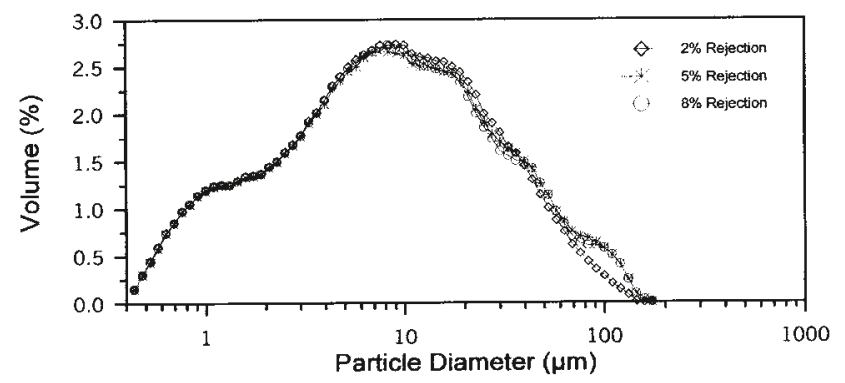

Figura 6.- Distribución del tamaño de partículas de los lotes correspondientes a diferentes rechazos.

Figure 6. Average particle size of the powders corresponding to the batches with different rejection levels (red stoneware). 
En la Figura 4 se recogen los datos del volumen y distribución de poros para ambas pastas. Se puede ver que el gres blanco presenta mayor porosidad y también mayor volumen de poros de mayor tamaño $(0.5-1 \mu \mathrm{m})$ que el gres rojo.

Los resultados de curvatura obtenidos para las baldosas recién sacadas de la estufa se muestran en la Figura 5, donde la línea continua indica la humedad antes de la medida y la línea discontinua la humedad después de la medida. La pasta blanca absorbe más cantidad de agua en cada pasada del rodillo húmedo pero también se evapora más rápidamente. Para humedades mayores de $0.8 \%$ en peso, para las que la placa ya se ha enfriado, la evaporación es mínima en ambas pastas. Por otro lado, contrariamente a lo que ocurría cuando las placas estaban a temperatura ambiente, las placas de gres blanco se curvan más que las de gres rojo, para el mismo contenido de agua.

En la Figura 6 se representa la distribución de tamaño de partícula correspondiente a los polvos preparados con distintos tiempos de molienda (Tabla 1). Se puede observar que no existen diferencias significativas entre los tres lotes para tamaños inferiores a $60 \mu \mathrm{m}$. Sin embargo, los lotes del $5 \%$ y $8 \%$ contienen un porcentaje mayor de partículas en el intervalo 100-200 $\mu \mathrm{m}$.

En las muestras preparadas con distintos niveles de rechazo se midió la curvatura en función de la humedad absorbida, de forma similar a la descrita anteriormente. Los resultados se representan en la Figura 7 para muestras prensadas a $25 \mathrm{MPa}$ a partir de los tres lotes. Como se puede observar, la curvatura aumentaba al disminuir el rechazo. En la Figura 8 se representa la variación de la curvatura con la humedad para las muestras del $8 \%$ de rechazo y distintas presiones de conformado, detectandose un aumento de la curvatura con la presión.

Según los datos del porcentaje de humedad absorbida por las baldosas en las distintas etapas de la línea de producción (Tabla 2), el mayor incremento se produce después del paso por las campanas, siendo los valores máximos alcanzados de $\sim 0.8 \%$ en peso para la pasta blanca y de $\sim 1 \%$ en peso para la roja.

En la Tabla 3 se recogen los datos del módulo de rotura en función de la humedad absorbida. Tanto la pasta blanca como la pasta roja disminuyen su módulo de rotura al absorber humedad.

En la Figura 9 se representan los resultados obtenidos del módulo de elasticidad en función de la humedad absorbida, observandose una disminución de esta propiedad con la humedad en ambas pastas, más acusada en el caso del gres blanco.

\section{DISCUSIÓN}

Para discutir el grado de penetración del agua consideramos el modelo sencillo de Washburn (3), que determina la distancia de infiltración de un líquido en un material poroso. Esta distancia, $x$, para un tiempo dado, $t$, es proporcional al radio de poro, r, según la ecuación:

$$
\frac{x^{2}}{t}=\frac{Y \cos (\varphi) r}{2 \mu}
$$

donde, $\mu$ es la viscosidad del fluido, Y la tensión superficial y $\varphi$ el ángulo de mojado.

Como el gres blanco presenta mayor porosidad y mayor volumen de poros grandes que el gres rojo (Figura 4), el agua se absorberá más rápidamente y penetrará una mayor distancia desde la superficie, ya que el resto de los parámetros de la
Figure 4 shows pore size distributions in both pastes. It can be seen that the white stoneware has greater porosity and also a higher volume of large pores $(0.5-1 \mu \mathrm{m})$ than the red stoneware.

The curvature results for the tiles directly taken from the oven are shown in Figure 5, where the continuos and dashed lines correspond to the water content before and after measurement, respectively. The white paste absorbs initially more water but it also evaporates more rapidly. For water absorption over $0.8 \mathrm{wt} . \%$ the pieces are already cold and water evaporation is negligible for both pastes. Conversely to the room temperature behaviour, the hot pieces of white stoneware curve more than the red stoneware for the same amount of absorbed water.

Figure 6 shows the particle size distributions corresponding to the powders prepared using different milling times (Table 1). No significant differences were observed between the three batches for particle sizes $<60 \mu \mathrm{m}$, although the $5 \%$ and $8 \%$ batches contained a higher percentage of large particles $(100-200 \mu \mathrm{m})$.

The curvature was also measured in the samples prepared using powders with different rejection levels as a function of the absorbed water, in a similar way to that described above. The results for samples pressed at $25 \mathrm{MPa}$ from the three batches are depicted in Figure 7, showing an increase in curvature when rejection diminished.

Figure 8 represents the change in curvature with water absorption for the samples fabricated with the $8 \%$ rejection batch and different forming pressures, where curvature raises with pressure.

Data in Table 2 show the percentage of absorbed water in the tiles at the different stages of the glazing line, the highest level occurs at the end of this process, reaching $\sim 0.8 \mathrm{wt} . \%$ for white paste and $\sim 1 \mathrm{wt} . \%$ for red paste.

In Table 3 the strength values for both pastes and different water contents are gathered. A reduction in strength with absorbed water is evident.

Figure 9 depicts the elastic modulus as a function of the absorbed water and, again, this property is seen to diminish with the amount of absorbed water in both pastes, although it is more pronounced in the case of the white stoneware.

\section{DISCUSSION}

Washburn's simple model (3) was considered to discuss the degree of water penetration within the tiles. This model determines the infiltration distance $(x)$ of a liquid in a porous material, for a given time $(\mathrm{t})$ and a pore radius $(\mathrm{r})$, according to the equation:

$$
\frac{x^{2}}{t}=\frac{Y \cos (\varphi) r}{2 \mu}
$$

where $\mu$ is the fluid viscosity, $Y$ the surface tension and $\varphi$ the wetting angle.

As the white stoneware had greater porosity and a higher volume of large pores than the red stoneware (Figure 4), the water will be more rapidly absorbed and will penetrate a longer distance from the surface, since other parameters of equation $\{1\}$ will be identical. Therefore, the water gradient within the tile will be smaller in the white paste which explains the smaller curvatures measured (Figure 3) for the 
TABLA 2- PORCENTAJES DE HUMEDAD ABSORBIDA POR LAS BALDOSAS EN LAS DISTINTAS ETAPAS DE LA LÍNEA DE PRODUCCIÓN, PARA LOS DOS TIPOS DE PASTA.

TABLE 2- AMOUNT OF ABSORBED WATER (IN WT. \%) AT SEVERAL STAGES OF THE GLAZING LINE FOR RED AND WHITE STONEWARE.

\begin{tabular}{|lc|c|}
\hline & Red stoneware & White stoneware \\
\hline Water spraying & 0.07 & 0.03 \\
Engobe application & 0.10 & 0.16 \\
Glazing & 0.55 & 0.85 \\
1st fixative & 1.02 & 0.65 \\
1st Silk screen printing & 1.00 & 0.70 \\
2nd Fixative & 1.12 & 0.70 \\
2nd Silk screen printing & 1.10 & 0.80 \\
Sorting & 1.07 & 0.80 \\
\hline
\end{tabular}

(ec.1) son idénticos. Por tanto, el gradiente de humedad dentro de la pieza es inferior en la pasta blanca y justifica que, para la misma cantidad de agua absorbida, la pasta blanca se curve mucho menos que la pasta roja (Figura 3). Este razonamiento es valido para un valor mínimo de agua absorbida, que según se de los datos de la Figura 3 sería del $\sim 1 \%$ en peso.

Cuando la aplicación de agua se realiza sobre la pieza caliente, las placas de gres blanco se curvan más que las de gres rojo (Figura 5). Este comportamiento, contrario al que tenían las placas a temperatura ambiente, se explicaría considerando que existe un gradiente de temperatura entre las superficies superior e inferior de las baldosas. Este gradiente térmico conducirá a una curvatura (4) opuesta a la que se produce por el gradiente de humedad. Dada la mayor porosidad de las placas de pasta blanca (Figura 4), estas absorberán mayor cantidad de agua que penetrará una distancia mayor, de forma que, el gradiente de temperatura en las baldosas de gres blanco será menor que en las de gres rojo. Por lo tanto, la curvatura opuesta asociada al gradiente térmico también será menor, lo que producirá una curvatura total mayor en la pasta blanca, como experimentalmente se observa.

Según se desprende de la Figura 7, existe un importante efecto de la porosidad en la curvatura: la curvatura de las piezas aumenta al disminuir el rechazo, esto es, el tamaño de poro. Según la ec.(1), para menores tamaños de poro la distancia de penetración del agua disminuye, por lo que el gradiente de humedad a través de la pieza crece, lo que se traduce en una mayor curvatura de la misma. En general, la porosidad debe disminuir al aumentar la presión de conformado por lo que la curvatura aumentará, como se observa experimentalmente (Figura 8).

Si consideramos los datos de humedad en línea (Tabla 2), se puede inferir que las baldosas de gres blanco se curvarán más que las del rojo sobre todo en el pasos por la primera campana, en que todavía están calientes las piezas, basándonos en los datos de la Figura 5. La Tabla 2 indica que la pasta blanca absorbe inicialmente más agua pero también la evapora antes, como sucedía en los ensayos de laboratorio con las pieza calientes. Al final del proceso de serigrafiado y antes de la entrada en el horno, la pasta roja conserva un mayor porcentaje de humedad.

Consideremos ahora los datos de resistencia y módulo de elasticidad en función de la humedad. La Tabla 3 muestra que para humedades similares a los valores máximos medidos en
TABla 3. Módulo de ROtURA DE MUESTRAS CRUdAS DE GRES EN FUNCIÓN DE LA HUMEDAD ABSORBIDA POR LA BALDOSA.

TABLE 3. FRACTURE STRENGTHS FOR GREEN STONEWARE SPECIMENS AT DIFFERENT WATER CONTENTS.

\begin{tabular}{|lc|}
\hline & Fracture strength (MPa) \\
\hline Dry red stoneware & $2.4 \pm 0.3$ \\
Red stoneware (1.3 wt.\% water) & $1.6 \pm 0.3$ \\
Dry white stoneware & $2.5 \pm 0.4$ \\
White stoneware (0.8 wt.\% water) & $1.5 \pm 0.2$ \\
\hline
\end{tabular}

same amount of absorbed water. This reasoning will be valid for a minimum level of absorbed water, that according to the data in Figure 3 would be of $\sim 1$ wt. $\%$.

When water is applied to the hot piece, the white stoneware tiles curve more than the red ones (Figure 5). This behavior is opposite to that observed in pieces at room temperature and it can be explained by the temperature gradient now existing between the upper and lower surfaces. This temperature gradient will produce a curvature (4) opposite to that produced by the water gradient. In fact, the white stoneware pieces will absorb a higher amount of water because of its higher porosity and it will penetrate a longer distance, equilibrating the temperature gradient across the piece. Hence, the opposite curvature associated with the temperature gradient will be smaller and will lead to a greater total curvature in the white stoneware, as experimentally observed.

As it can be seen in Figure 7, porosity has a significant effect on curvature. For a fixed percentage of water, the curvature of the pieces increases when rejection level decreases, i.e. as the pore size diminishes. If the pore size decreases, the penetration distance would be smaller according to equation (1) which gives higher water gradient and therefore a greater curvature. In general, porosity should decrease as the forming pressure increases, which corresponds with an augment in the curvature, as experimentally observed (Figure 8).

When the data for water absorption along the line (Table 2) are considered, the pieces of white stoneware should curve more than the red stoneware, according to Figure 5, especially in the first glazing stage where they are still hot. From Table 2 it can be assumed that the white paste absorbs initially more water, but it also evaporates faster, as occurred in the laboratory experiments (Figure 5). At the end of the production line, red stoneware retained a higher percentage of water (Table 2).

Let us now consider the strength and the elastic modulus data as a function of the water content. Table 3 shows that for water content corresponding to the maximum level on the production line $(\sim 1 w t . \%)$, a significant reduction in the strength of the pastes is detected: $33 \%$ for the red paste and $40 \%$ for the white paste. Although these data refer to small laboratory samples, they can easily be applied to whole tiles. In other words, both the white and red stoneware tiles become more brittle with the water content. This trend is contrary to that reported for the fracture strength of green stoneware pieces measured as a function of the water content in the powders before pressing $(2,5)$. Thus, it is obvious that these two types of water absorptions have different effects on the pastes. 
la línea de producción (Tabla 2) se detecta un descenso importante de la resistencia mecánica de las piezas: $33 \%$ para la pasta roja y $40 \%$ en la pasta blanca. Aunque estos datos se refieren a pequeñas muestras de laboratorio, son totalmente trasladables a baldosas enteras. Es decir, que las baldosas crudas, tanto de pasta blanca como de roja, se hacen más frágiles con la humedad absorbida. Esta tendencia es opuesta a lo que se observa cuando se compara la resistencia mecánica de pastas crudas de gres en función de la humedad de prensado (2, 5). Es, pues, evidente que estos dos tipos de humedad tienen efectos distintos sobre las pastas.

Señalando en la Figura 9 las líneas que indican la humedad máxima de cada tipo de pasta en la línea de producción, se puede observar que corresponde con una disminución del módulo de elasticidad dinámico de $\sim 19 \%$ para la pasta roja y $\sim 37 \%$ para la pasta blanca. Dicha disminución del módulo de elasticidad con la humedad es mucho mayor para la pasta blanca, es decir, las baldosas pierden rigidez con la humedad y la pasta blanca de una forma más acusada.

Las tensiones asociadas con la curvatura que sufren las piezas se pueden estimar mediante expresiones de la teoría de Elasticidad y simples modelos geométricas (6). La deformación en la capa superior (máxima) se puede calcular a partir del desplazamiento del punto medio, según la expresión:

$$
\varepsilon=\frac{4 h}{s^{2}} \delta
$$

donde $\varepsilon$ es la deformación, $\delta$ el desplazamiento, h el espesor y $S$ la longitud de la placa (Figura 10). Sustituyendo los correspondientes valores para los distintos tipos de pasta, se obtienen los valores de la deformación que se recogen en la Tabla 4.

Durante el serigrafiado, el paso de la rasqueta produce una deformación opuesta a la que inicialmente tiene la placa y, por lo tanto, aparece una tensión en la baldosa. Como estado inicial consideraremos las piezas curvadas, con una humedad $\sim 1 \%$ en peso (humedad en la línea a partir del $1^{\mathrm{er}}$ fijador en la

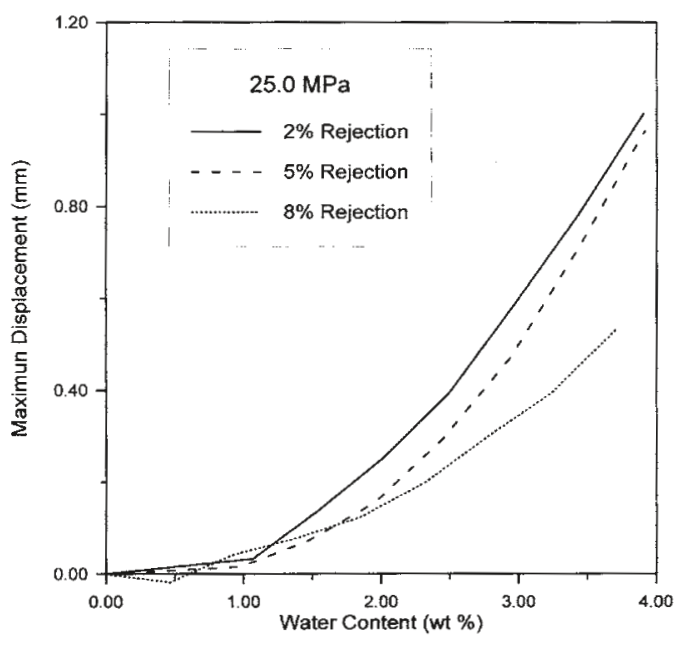

Figura 7.- Desplazamiento del punto medio en función del agua absorbida a temperatura ambiente para las placas con distintos niveles de rechazo, prensadas a $25 \mathrm{MPa}$.

Figure 7. Displacement of the plate vs the amount of absorbed water (room temperature) for the different rejections and a forming pressure of $25 \mathrm{MPa}$.
The lines indicating the maximum water content for each paste on the production line are included in Figure 9. It can be observed that they correspond to a decrease in the dynamic elastic modulus of $\sim 19 \%$ for the red paste and $\sim 37 \%$ for the white paste. Although the trends are similar in both pastes, the reduction in the elastic modulus with absorbed water is much greater for the white paste. Consequently, tiles lose rigidity with water content, particularly in the case of the white stoneware.

The stresses associated with the curvature of the pieces can be estimated from Elasticity equations and simple geometrical considerations (6). The maximum deformation of the upper layer can be calculated from the displacement of the middle point of the specimen, according to the equation:

$$
\varepsilon=\frac{4 h}{s^{2}} \delta
$$

where $\varepsilon$ is the deformation, $\delta$ the displacement, $\mathrm{h}$ the thickness of the piece and $S$ the length of the piece (Figure 10). When the corresponding figures for the different types of pastes are used, the deformation levels shown in Table 4 are calculated.

During the silk-screen printing process, a deformation opposite to that of the initial piece occurs and stress develops in the tile. Let consider the curved pieces as the initial state, with a water content of $\sim 1 w t . \%$ (maximum water absorption on the glazing line). Assuming that tiles are hot, a displacement of the middle point of the piece of $\sim 0.2 \mathrm{~mm}$ for the red paste and of $\sim 0.4 \mathrm{~mm}$ for the white paste are calculated (Figure 5). According to Hooke's law (7), the stress to which the piece would be subjected would simply be given by:

$$
\sigma=E \cdot \varepsilon
$$

Using the values of absorbed water $\varepsilon$ in Table 4 and the corresponding values of $\mathrm{E}$ for $1 \mathrm{wt} . \%$ (Figure 9), $\mathrm{E}_{\text {Pred }}=\sim 5.25$

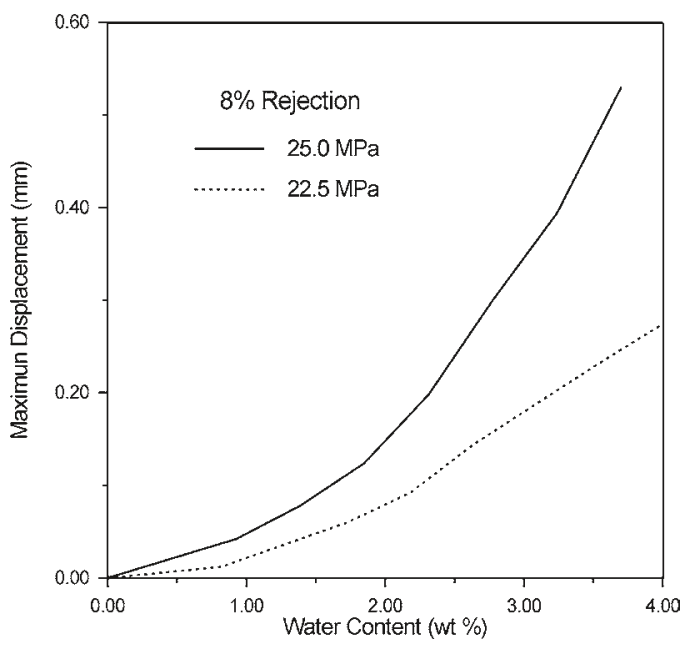

Figura 8.- Desplazamiento del punto medio de las placas de referencia $8 \%$ (ver texto) prensadas a 25 y $22.5 \mathrm{MPa}$ en función del agua absorbida a temperatura ambiente.

Figure 8. Displacement of the plate vs of the amount of absorbed water (room temperature) for the $8 \%$ rejection batch at two forming pressures (22.5 and $25 \mathrm{MPa})$. 
pasta roja). Si suponemos que las piezas están calientes, esto nos daría un desplazamiento del punto medio de la pieza de $\sim 0.2 \mathrm{~mm}$ para la pasta roja y de $\sim 0.4 \mathrm{~mm}$ para la pasta blanca (Figura 5). Según la ley de Hooke (7), la tensión a la que se vería sometida la pieza, vendría simplemente dada por:

$$
\sigma=E \cdot \varepsilon
$$

Utilizando los valores de $\varepsilon$ de la Tabla 4 y los correspondientes valores de $\mathrm{E}$ para $\sim 1 \%$ en peso de humedad, según la Figura 9, $\mathrm{E}_{\text {Proja }}=\sim 5.25 \mathrm{GPa}$ y $\mathrm{E}_{\text {Pblanca }}=\sim 4 \mathrm{GPa}$, y sustituyendo en la expresión anterior, se obtiene:

$$
\begin{aligned}
& \sigma_{\text {Proja }}=0.31 \mathrm{MPa} \\
& \sigma_{\text {Pblanca }}=0.42 \mathrm{MPa}
\end{aligned}
$$

Según el cálculo realizado, las baldosas cerámicas como consecuencia de su curvatura estarían sometidas a tensiones del orden de $0.31 \mathrm{MPa}$, el gres rojo, y $0.42 \mathrm{MPa}$, el gres blanco; ambas muy inferiores a los valores de resistencia mecánica determinados en baldosa enteras: 2.5 y 3.1 MPa [8], respectivamente. Incluso si se considera que para humedades del $1 \%$ en peso, las baldosas han disminuido su resistencia mecánica en seco, en $\approx 33 \%$ ( pasta roja) y en $\approx 40 \%$ (pasta blanca), las tensiones a que están sometidas seguirían siendo inferiores en un orden magnitud a la resistencia mecánica de las piezas. Es decir, las piezas no se romperían como consecuencia de las deformaciones que acarrea la curvatura de las mismas.

Según la discusión de los datos, se puede asegurar que la pasta blanca se comportará mejor durante el proceso en linea como consecuencia de su menor rigidez, incluso favorecida por la ganancia de humedad, lo que permite prever un menor porcentaje de roturas.

\section{CONCLUSIONES}

La curvatura de baldosa crudas de gres como consecuencia de la humedad absorbida es función de la porosidad y del tamaño medio de los poros. Cuanto menor sea el tamaño de poros mayor será el grado de curvatura, mientras que lo contrario ocurre cuando las piezas están calientes. Tanto la resis-

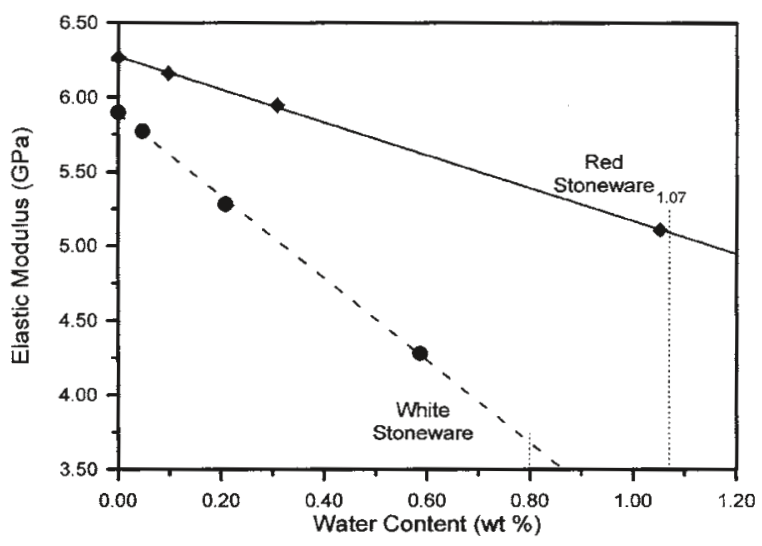

Figura 9.- Modulo de elasticidad dinámico de ambas pastas en función de la humedad absorbida.

Figure 9. Dynamic elastic modulus vs water content for red and white stonewares.
TABla 4- VAlores Utilizados PARA El CÁlCUlo DE LA DEFORMACIÓN DE LAS BALDOSAS (VER TEXTO) ASOCIADA A LA CURVATURA, PARA LOS CONTENIDOS MÁXIMOS DE AGUA EN LÍNEA DE PRODUCCIÓN.

TABLE 4- PARAMETERS USED TO CALCULATE MAXIMUM DEFORMATION LEVELS IN BOTH STONEWARE TILES (SEE TEXT) FOR THE MAXIMUM WATER CONTENTS IN THE GLAZING LINE.

\begin{tabular}{|l|c|c|c|c|}
\hline & $\mathbf{S} \mathbf{( c m )}$ & $\mathbf{( c m )}$ & $\mathbf{h} \mathbf{( c m )}$ & \\
\hline Red stoneware & 33 & 0.02 & $\sim 0.8$ & $5.87 \cdot 10^{-5}$ \\
White stoneware & 34.5 & 0.04 & $\sim 0.8$ & $1.07 \cdot 10^{-4}$ \\
\hline
\end{tabular}

GPa y $E_{\text {pwhite }}=\sim 4 \mathrm{GPa}$, and substituting these in the above equation, it is obtained:

$$
\begin{aligned}
& \sigma_{\text {Pred }}=0.31 \mathrm{MPa} \\
& \sigma_{\text {Pwhite }}=0.42 \mathrm{MPa}
\end{aligned}
$$

According to these calculations, ceramic tiles are subjected to stresses, as a result of their curvature of around $0.31 \mathrm{MPa}$ in the case of red stoneware and $0.42 \mathrm{MPa}$ in that of white stoneware, both far below the strength levels determined in whole tiles for both pastes: 2.5 y 3.1 MPa [8] respectively. Even considering that for $1 \mathrm{wt}$.\% of absorbed water the tiles have reduced their dry strength by around 33\% (red paste) and $40 \%$ (white paste), the stresses to which they are subjected would still be one order of magnitude lower than the ultimate strength of the tiles. In other words, the pieces would not fracture as a result of the deformations caused by their curvature along the production line.

Accordingly, it can be stated that the white paste will behave better along the production line as a result of its lower rigidity that even benefits from the gain in water, which gives lower percentage of fractures for this paste.

\section{CONCLUSIONS}

Curvature of green stoneware tiles as a result of the water absorbed in the production line depends on porosity and average size of the pores. The smaller the pores the greater the degree of curvature, while the opposite occurs when the pieces are hot. Both the strength and the elastic modulus of the green pieces decrease with the percentage of absorbed water, albeit in different proportions depending on the type of paste.

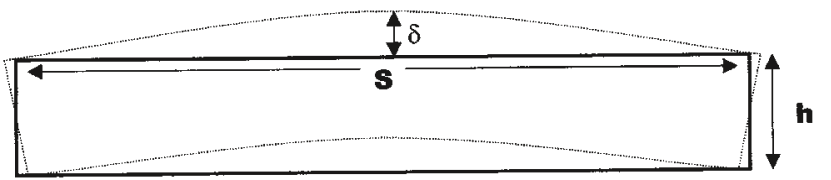

Figura 10.- Modelo geométrico utilizado para el calculo de la deformación.

Figure 10. Geometric model geometry used to calculate strain in the bend plates. 
tencia mecánica de las piezas crudas como el módulo de elasticidad disminuyen con el porcentaje de humedad absorbida, aunque en proporciones distintas según el tipo de pasta.

\section{BIBLIOGRAFÍA / REFERENCES}

1. A. S. Jayatilaka, Fracture of Engineering Brittle Materials, pp 29-33. Ed. Applied Science Publishers, Ltd., Londres 1979.

2. A. P. Novoaes de Oliveira, T. Manfredini, “Un modelo para predecir la resistencia mecánica de una pieza cerámica en crudo", Qualicer 96, Castellón(España), 439-448 (1996).
3. E. W. Washburn, "The dynamics of capillary flow" Am. Phys. Soc. 17 374-75 (1921).

4.V. S. Kienow, Rißbildung in gebranten Konvertersteinen" Ber.Dt. Keram. Ges. 47 426-30 (1970).

5. J. L. Amorós, C. Feliú, F. Ginés, J. V. Agramunt, “Resistencia mecánica y microestructura de soportes cerámicos en crudo", Qualicer 96, Castellón (España), 153-170 (1996)

6. T. Fett, K. Keller, M. Missbach, D. Munz, “Creep parameters of alumina containing a glass phase determined in bending creep tests" J. Am. Ceram.Soc. 71 1046-49 (1988)

7. S. Timoshenko y J. N. Goodier, “Teoria de Elasticidad” $2^{a}$ edición, pp 27-31.Ed. Urmo S.A., Bilbao, 1968.

8. Informe técnico ICV-Gres de Nules 1988, trabajo no publicado. 